УДК 378.018.8:373.5.011.3-051:74](043.3)

DOI:

Микола Пічкур, кандидат педагогічних наук, дочент, професор кафедри образотворчого мистецтва

Уманського державного педагогічного університету імені Павла Тичини

\title{
ФОКУС РЕЗУЛЬТАТИВНОСТІ БАЗОВОГО ПРОФЕСІЙНОГО ЕТАПУ ОБРАЗОТВОРЧОЇ ПІДГОТОВКИ МАЙБУТНІХ ФАХІВЦІВ МИСТЕЦЬКИХ СПЕЦАЛЬНОСТЕЙ
}

У статті позииіоновано образотворчу підготовку в галузевій системі мистецьких спеціальностей закладів вищої освіти та доведено, що ї̈ результативність доцільно регламентувати професіографічними дескрипторами зображальної грамоти і художньої майстерності. 3'ясовано, що в арт-педагогічному процесі допускається дисбаланс у формуванні иих особистісно-професійних якостей студентів. Розкрито причину його виникнення, щчо полягає у наданні переваги одному з критерїв реалістичності й образності в досягненні художньої якості виконання навчально-творчих завдань із фахових дисциплін.

Ключові слова: образотворча підготовка; професіографічні дескриптори; майбутні фахівці мистеиьких спеціальностей; зображальна грамота; художня майстерність.

Puc. 1. Лim. 12.

Mykola Pichkur, Ph.D. (Pedagogy), Associate Professor, Professor of the Fine Art Department, Uman Pavlo Tychyna State Pedagogical University

\section{THE FOCUS OF EFFECTIVENESS OF THE BASIC PROFESSIONAL STAGE OF FINE ART TRAINING FOR WOULD-BE PROFESSIONALS OF ART SPECIALTIES}

The article identifies fine art training in the system of art specialties (fine art teachers, artists of fine and decorative art, artists-restorers, art critics and architectures) of institutions of high education. In the focus of educational and professional programs the appropriateness of its effective regulating with professional and graphic specific features of a definite profession has been highlighted.

Based on the sense of the conceptions "profession", "professional", "specialist" the following summary has been revealed: in high education in the context of identified profession the applying specialty, art specialty in particular, is presented by two necessary and appropriate professional and graphic features of vocational training. They are literacy (knowledge, abilities and skills) and professional skills (job skillfulness).

Taking into consideration the mix of canonic, academic, ethnic and cultural, cultural and synthetic, operative, creative and uncontrolled models of basic professional stage of fine art training, the presence of specific features, diversity and difference of its results have been indicated. It has been proved that for every art specialty they should be presented by the single professional and graphic specific feature like "descriptive literacy" and "art skillfulness".

Using the materials on art criticism, art and pedagogical information, the preceding fact has been statedduring fine art training for would-be professionals of art specialties at high school based on the results of educational and creative activities the following contradictions have been confirmed: between the image realty and artistic value of the object pictured; between descriptive literacy as a main factor of educational and creative works producing and their artistic features; between descriptive literacy in learning its academic basis and the quality of fine art producing in the context of presenting of objects illusion and real phenomena. The reason for present disbalance in the forming of descriptive literacy and the students' art skillfulness that implies in emphasizing at realty or imagery has been revealed. They may perform as the art criteria in the process to reach qualitative art work producing in educational and creative contexts.

Keywords: fine arts training; professional descriptors; future specialists in artistic specialties; descriptive literacy; art skillfulness.

П остановка проблеми. У сучасних умовах світової глобалізації людство зміщує свій інтерес від технократичних до антропогенних цінностей, що вимагає від кожного індивіда засвоєння естетичної культури та формування моделі відповідної поведінки для подальшого розвитку й реалізації творчого потенціалу. Саме тому, як слушно наголошує Г. Сотська, "в умовах соціально-економічних, науково-технічних та культурних змін в Україні національна освіта зорієнтована на задоволення запитів різних галузей науки, техніки, економіки в компетентних, кваліфікованих спеціалістах 3 високим рівнем культури, духовності, соціальної й творчої активності" $[10,10]$. Таке цільове спрямування пріоритетне для особистісноформувальної і творчо-розвивальної за своєю сутністю мистецько-освітньої галузі, що неодмінно 


\section{ФОКУС РЕЗУЛЬТАТИВНОСТІ БАЗОВОГО ПРОФЕСІЙНОГО ЕТАПУ ОБРАЗОТВОРЧОЇ ПІДГОТОВКИ МАЙБУТНІХ ФАХІВЦІВ МИСТЕЦЬКИХСПЕЦІАЛЬНОСТЕЙ}

грунтується на аксіологічних та гуманістичних засадах.

У процесі гуманізації мистецької освіти важливу роль відіграє реалізація директив аналітичного документа "Мистецька освіта в Україні: розвиток творчого потенціалу в XXI столітті" (2012) та “Національної стратегї̈ розвитку освіти в Україні на 2012-2021 роки”, спрямованих на збереження і примноження цінностей національної художньої культури.

У контексті методології гуманістичного підходу слушною є думка О. Пономарьової, що особливим питанням мистецької освіти залишається необхідність формування відповідального ставлення майбутніх фахівців до надбань культури, до особистої художньо-творчої діяльності, результати якої завжди впливають на людину як споживача певних артефактів [9, 57]. Із урахуванням цього, сучасний митець у процесі професійної підготовки в закладах вищої освіти має набути статусу справжнього майстра своєї справи, здатного продукувати об'єктивно ціннісні художні твори. Досягнення цієї мети залежить від глибокого осмислення інноваційних процесів у культурі і мистецтві та їх екстраполювання в систему вищої мистецької освіти з урахуванням сучасних європейських вимог до її організації в змістово-процесуальному, особистісно-формувальному та результативному аспектах.

Аналіз останніх досліджень і публікацій. У вітчизняній теорії і практиці вищої мистецької освіти загальнотеоретичні аспекти професійної підготовки майбутніх фахівців художніх спеціальностей, у тому числі й образотворчих, розкрито у наукових працях Н. Кубриш, В. Орлова, О. Отич, О. Пономарьової, Т. Руденької,О. Рудницької, Ю. Самойленка, О. Шевнюк та інших ученихпедагогів сучасності.

Останніми роками виконано чимало педагогічних досліджень, які прямо чи опосередковано стосуються образотворчого контексту фахової підготовки майбутніх архітекторів (М. Габрель, В. Григор'єва, О. Кайдановська, С. Карпова, Ю. Ларіонов та ін.); дизайнерів (О. Баніт, Т. Мала, Л. Полудень, А. Семенюк, В. Прусак та ін.); художників декоративного мистецтва (Є. Антонович, М. Близнюк, О. Власюк, Л. Оршанський, Р. Шмагало та ін.) та вчителів образотворчого мистецтва (А. Гордаш, О. Семенова, О. Сова, Г. Сотська, Я. Твердохлібова та ін.). Водночас, у теорії і методиці професійної освіти художниківреставраторів, живописців, графіків та скульпторів нині обмаль наукових напрацювань із питань їхного образотворчого вишколу.
Згідно з чинними стандартами вищої освіти України, в освітньо-професійних програмах неодмінно прописується комплекс інтегральних, загальних і фахових компетентностей. Проте стосовно образотворчого фаху у них бракує чіткого визначення освітнього фокусу у вимірах зображальної грамоти і художньої майстерності. Це засвідчує суперечність між потребою уніфікації результативності процесу образотворчої підготовки та іï диверсифікацією через надання переваги формуванню специфічних здатностей майбутніх фахівців мистецьких спеціальностей у межах окремих професійних кваліфікацій.

Мета статті- обгрунтувати професіографічні дескриптори зображальної грамоти і художньої майстерності та довести, що саме вони $є$ фокусом результативності базового професійного етапу образотворчої підготовки майбутніх фахівців мистецьких спеціальностей.

Виклад основного матеріалу дослідження. У сучасному науковому обігу поняття "митець" вживається в значенні творчої особистості, яка присвятила свій життєвий шлях і трудову діяльність продукуванню високохудожніх творів. У такому термінологічному сенсі митцями називають фахівців різних галузей мистецтва, приміром, письменників, музикантів, театралів, художників тощо. Усі ці професії належать до автономічної предметної системи праці “людина - художній образ". Серед них вирізняється категорія “фахівці образотворчого профілю”, якою позначають певну спільноту митців різних художніх спеціальностей. Згідно 3 цим, в Україні у формі громадських творчих організацій функціонують обласні і національні спілки дизайнерів, художників, архітекторів, а також регіональні осередки майстрів декоративного мистецтва та районні методичні об'єднання вчителів образотворчого мистецтва.

На теренах сьогодення будь-який образотворчий фах дедалі більше набуває інтегрованого статусу, оскільки джерелами образотворення $є$ результати суспільної практики в їі матеріальному і духовному контекстах. Підтвердженням цієї позиції слугує думка сучасного вітчизняного естета і культуролога В. Гриценко про те, що художній образ є унікальною формою трансформації людської практики в художню реальність, спосіб художньої реконструкції дійсності з позицій суспільних потреб та людських уявлень про досконалість, тобто універсалією, в якій естетичне реалізується сповна $[5,25]$. Це відбувається в різних видах мистецтва, котрі, як слушно наголошує С. Безклубенко, завжди є продукуванням, 


\section{ФОКУС РЕЗУЛЬТАТИВНОСТІ БАЗОВОГО ПРОФЕСІЙНОГО ЕТАПУ ОБРАЗОТВОРЧОЇ ПІДГОТОВКИ МАЙБУТНІХФАХІВЦІВ МИСТЕЦЬКИХСПЕЦІАЛЬНОСТЕЙ}

виробництвом творів за критерієм художності як майстерності, з якою виготовлено річ, та цілісності образу того, що становить предмет зображення чи зміст самовираження [1, 226-227]. учителів образотворчого мистецтва, художників образотворчого та декоративного мистецтва, художників-реставраторів, мистецтвознавців, дизайнерів та архітекторів (рис. 1).

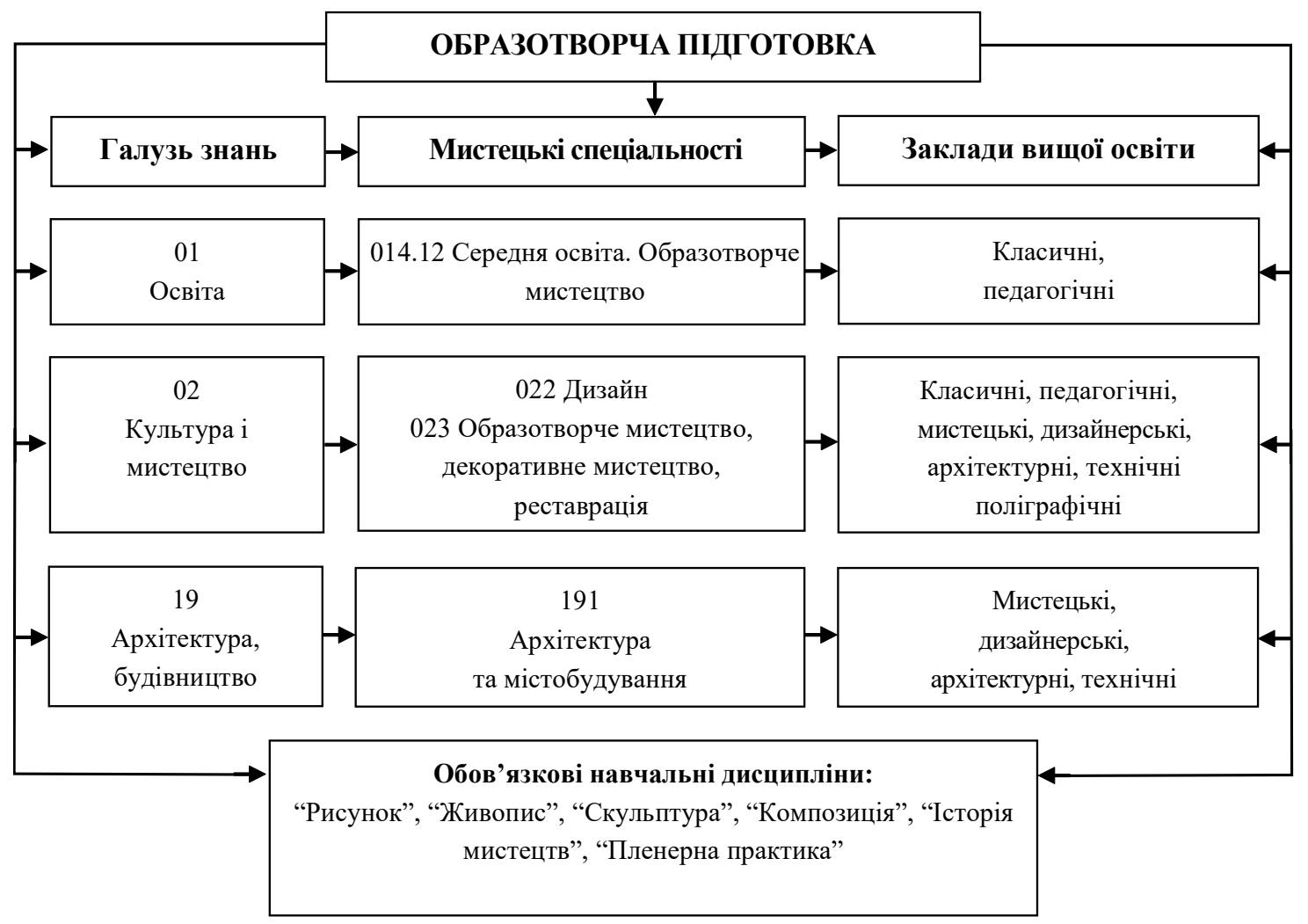

Рис. 1. Образотворча підготовка в галузевій системі мистецьких спеціальностей закладів вищої освіти

За визначенням А. Гордаша, художня майстерність особистості фахівця образотворчого профілю позначається розвиненим естетичним сприйняттям об'єктів і явищ довкілля та художньої культури, художньо-естетичним смаком, сформованим умінням мислити образами, глибоким розумінням специфіки мови мистецтва, віртуозним володінням його засобами i технічними прийомами й здатністю за допомогою них досягати високої художності й оригінальності продукованого твору [4, 8]. Незважаючи на поширення компетентнісного підходу в мистецькій освіті, художня майстерність більше стосується професіографічної методології, у межах якої її варто кваліфікувати як особистісно-професійну якість, що формується на допрофесійному, базовому професійному, післяпрофесійному етапах образотворчої підготовки та впродовж усього життя.

Згідно 3 переліком галузей знань i спеціальностей, у закладах вищої освіти України здійснюється базова професійна підготовка
Отже, згідно 3 рис. 1, найважливішим та уніфікованим сегментом системи вищої освіти із зазначених спеціальностей разом із можливими спеціалізаціями є образотворча підготовка, у процесі якої за художньо-педагогічною методологією комплексного навчально-творчого підходу студіюються такі обов'язкові навчальні дисципліни, як “Рисунок”, “Живопис", “Скульптура”, “Композиція”, “Історія мистецтв”, "Пленерна практика".

Відповідно до чинного Національного класифікатору України ДК 003:2010 “Класифікатор професій” студенти класичних, педагогічних, мистецьких, дизайнерських, архітектурних і технічних закладів вищої освіти здобувають відповідну кваліфікацію, що в Законі України “Про вищу освіту” (2014) результативно регламентується “дублінськими дескрипторами": a) знання і розуміння; б) застосування знань; в) формулювання суджень; г) комунікативні вміння; д) здатність до самостійного навчання [12]. Ці дескриптори охоплюють певну сукупність 
компетентностей, що визначається з урахуванням фаху митця, предмету, специфіки і функцій його професійної діяльності та найважливіших професійно-особистісних детермінант теоретичної, практичної і психологічної готовності до успішного виконання завдань художньої творчості у процесі кваліфікованої праці. Усе це заломлюється у фокусі освітньо-професійних програм як осередку, в якому акумулюються необхідні і достатні для будь-якої мистецької спеціальності професіографічні дескриптори образотворчої підготовки.

Слід зазначити, що “дескриптор” (з англ. Descriptor - описувач, указівник) - це стандартизоване, ключове або базове поняття, що міститься в тезаурусі (словнику) певної галузі знань. Термін “професіографія" походить від лат. "professio" - постійний фах, джерело існування та грец. "grapho" - пишу. Звідси, словосполучення “професіографічний дескриптор” означає основні репрезентативні ознаки того чи того фаху у межах конкретної професії.

Варто наголосити, що слово “фах” за своїм змістом можна трактувати вужче, ніж термін “професія", або ідентично йому. Але в російській мові такої двозначності бракує: українська лексема “фах" у російському перекладі звучить однозначно - “профессия". Саме тому будь-якою професією передбачено широку галузь застосування праці за комплексом кваліфікацій чи спеціальностей. Натомість поняття “фах” устелено розуміється як володіння конкретною спеціальністю за певним рівнем ії кваліфікації, що $\epsilon$ результатом спеціальної підготовки в закладах освіти у межах класифікатора відповідних професій. Щоб довести це твердження, звернемось до довідникових джерел.

Поняття "фах" однозначно розуміється як основна кваліфікація, спеціальність людини в трудовій діяльності, у межах якої вона демонструє свої вміння, майстерність і хист. У філологічному контексті семантика слова “фах" охоплює відділення, частину, ділянку, галузь науки, предмет навчання. Зазвичай ця лексема ототожнюється 3 поняттям “вид діяльності”, що конкретизується такими відповідними словосполученнями, як “галузева професія”, “окрема галузь професійної діяльності”, “вид професійної діяльності”, “професійна діяльність у межах окремої галузі”, “окрема ділянка професійної діяльності”, “професійна діяльність щодо чого-небудь”, “галузева діяльність” [7, 93].

Отже, загальна сутність поняття “фах” полягає в тому, що це обраний людиною конкретний різновид кваліфікованої праці в межах певної галузі професійної діяльності. Завдяки спеціальній підготовці й успішному здобуттю відповідної освіти (підтверджується дипломом) випускника вишу приймають на відповідну роботу, у процесі якої при виконанні трудових функцій він реалізує свої здібності демонструє майстерність і таким чином набуває статусу справжнього фахівця.

В “Українському педагогічному словнику" поняття “фахівець” тлумачиться як “спеціаліст, професіонал, майстер (рос. мастер, англ. master, foreman, expert, нім. fachmann), людина, яка досконало володіє якимось фахом, має високу кваліфікацію, глибокі знання з певної галузі науки" $[3,481]$. Відтак, фахівцем є та людина, яка у ході підготовки в закладах освіти сформувала професійно важливі особистісні якості для відданого і майстерного виконання трудових завдань і набуття статусу спеціаліста.

В “Енциклопедії освіти” міститься два тлумачення терміна “спеціаліст” 1) особа, яка досягла високої майстерності в чому-небудь, знавець чогось, фахівець; 2) освітньокваліфікаційний рівень особи, яка на основі освітньо-кваліфікаційного рівня бакалавра здобула повну вищу освіту, спеціальні уміння та знання, має певний досвід їх застосування для виконання завдань та обов'язків певного рівня професійній діяльності, передбачених для відповідних посад у певній галузі господарства [6, 842].

Таким чином, розуміння сутності поняття “спеціаліст" зводиться до результативності набуття людиною в системі професійної освіти обраного фаху, що атрибутивно приписує йому ту чи ту спеціальність за параметрами готовності якісно виконувати трудові функції. Очевидно, що в цьому компетентнісному контексті простежується категоріальна ознака молодого фахівця, котрий, на відміну від зрілого фахівця, не має достатнього практичного досвіду роботи, а тому його статус спеціаліста і тим більше професіонала є лише потенційним. У такому разі вихідна сутність терміна “спеціаліст” однозначна - особа, яка володіє спеціальними знаннями, уміннями і навичками і в межах набутої кваліфікації здатна ними скористатися в процесі трудової діяльності.

Із окресленого термінологічного аналізу, можна зробити узагальнення, що на рівні вищої освіти здобуття в межах обраного фаху певної спеціальності, у тому числі і мистецької, неодмінно репрезентується двома необхідними і достатніми професіографічними дескрипторами професійної підготовки - грамота (знання, уміння і навички) і майстерність (трудова вправність).

За твердженням I. Лєвіна, на базовому професійному етапі образотворча підготовка 


\section{ФОКУС РЕЗУЛЬТАТИВНОСТІ БАЗОВОГО ПРОФЕСІЙНОГО ЕТАПУ ОБРАЗОТВОРЧОЇ ПІДГОТОВКИ МАЙБУТНІХ ФАХІВЦІВ МИСТЕЦЬКИХСПЕЦІАЛЬНОСТЕЙ}

майбутніх фахівців мистецьких спеціальностей $\epsilon$ симбіозом їі різних моделей: канонічної (відтворення зразків), академічної (відображення об'єктивної реальності), етнокультурної (засвоєння художніх традицій), культурносинтетичної (діалог культур), діяльнісної (активне варіювання засобів зображення), креативної (авторський пошук образотворчих засобів), довільної (за індивідуальним вибором самовираження) [8, 54-55]. Проте якими б специфічними, численними й різноплановими не були результати образотворчої підготовки щодо зазначених їі моделей, вони мають бути представлені такимиуніфікованимипрофесіографічними дескрипторами, як “зображальна грамота” i "художня майстерність".

Мистецько-освітня практика засвідчує, що на теренах минулого і сьогодення нерідко спостерігається певний дисбаланс у формуванні зображальної грамоти і художньої майстерності студентів, причиною якого $є$ надання переваги реалістичності чи образності як критеріїв художності в досягненні якості виконання мистецького твору у навчальному і творчому контекстах. Спробуємо експлікувати це на мистецтвознавчому та художньо-педагогічному матеріалі.

В історії китайської філософії мистецтва відомий факт диференціації художників на ранги відповідно до їхніх переваг щодо активізації певних психофізіологічних детермінант образотворення - око, рука, серце, розум. Згідно 3 цим, художник-візуал довіряє зору беззастережно і малює, що і як бачить. Майстер рукоремесла віртуозно володіє технологією художніх матеріалів, його твори прекрасні і технічно досконалі, але позбавлені енергетики. Кардіомитець завжди прагне не залишити нікого байдужим від споглядання твору, але його роботи недостатньо грамотні в зображувальному і технологічному планах. Художник-мудрець глибоко усвідомлює, що він робить, навіщо і чому створює ту чи ту картину, але його креатив домінує, підпорядковуючи всі виражальні засоби процесу втілення ідеї.

Отже, око і рука працюють на відтворення реальності. Почуття організують образ і роблять зображення максимально виразним. Від усвідомлення того, ким хоче і має стати художник відповідно до обраного фаху, ураховується специфіка його образотворчої підготовки. Але в будь-якому разі їі основою $є$ тривалий, наполегливий і працелюбний вишкіл реалістичної зображальної грамоти і художньої майстерності. Про це свідчить багатий вітчизняний мистецько- освітній досвід, що зафіксований у теоретикопрактичній спадщині видатних художниківпедагогів. Так, Д. Кардовський наголошував, що вчитися малювати необхідно довго, вдумливо, розумно, наполегливо, вивчаючи натуру, адже майстерність - це, передусім, результат важкої праці.

Загальну сутність поняття “зображальна грамота" полягає у володінні системою законів і правил образного відображення дійсності художніми засобами різних видів мистецтв. Якщо його розглядати в образотворчому контексті, то конкретика виявиться в умінні і навичках митця ілюзорно відтворювати реальні об'єкти чи явища на зображувальній площині графічними, колірними, світло-тіньовими, формотвірними та іншими засобами. Така грамотність формується у студентів у процесі вивчення фахових дисциплін.

В окресленому значенні зображувальна грамота є лише першоосновою для становлення і розвитку художньої майстерності, що, за визначенням А. Гордаша, $\epsilon$ “провідною професійно-індивідуальною якістю митця у вимірах його непересічного естетичного смаку, талановитості, геніальності, умілості, вправності, ремісничості, мистецькості, артистизму, досвідченості та здатності захоплено продукувати об'єктивно-ціннісні твори, що мають провідні ознаки художності, естетичності, образності, досконалості, витонченості, шедевральності" [4, 7]. Це означає наявність певного дисонансу.

По-перше, дисбаланс між реалістичністю зображення і художньою цінністю того, що змальовано. Адже іноді суворе дотримання положень зображальної грамоти шкодить емоційному й образному сприйняттю твору, що набуває рис штучності. Практика свідчить, що найчастіше художньо-образні пошуки митця виглядають переконливіше, ніж максимально реалістично, правдиво і технічно майстерно виконані зображення. 3 історії мистецтва відома оповідь про I. Гете, який, будучи свідком того як відвідувачі літнього кафе сплутали справжні плоди винограду з майстерно змальованим гроном цих ягід та мухами на них, сказав: "Не все те є мистецтвом, на що сідають мухи”. Звісно, це жартівлива сцена, але вона цілком образно показує, що істинну цінність художньої творчості визначає не лише скрупульозне реалістичне зображення, а дещо більш складне. Цю думку підтверджує позиція О. Ренуара про те, що мистецтво має бути неймовірним і неповторним.

По-друге, відчутний дисонанс між зображальною грамотою як домінантою процесу образотворчої підготовки майбутніх фахівців 


\section{ФОКУС РЕЗУЛЬТАТИВНОСТІ БАЗОВОГО ПРОФЕСІЙНОГОЕТАПУ ОБРАЗОТВОРЧОӤ ПДГОТОВКИ МАЙБУТНІХ ФАХІВЦІВ МИСТЕЦЬКИХСПЕЦАЛЬНОСТЕЙ}

мистецьких спеціальностей у вищій школі і критерієм художності студентських навчальнотворчих продуктів. Тобто те, що добре виконано 3 кута зору реалістичності і правильності зображення, може мати незначну художню цінність. Натомість поняття “художність” має два значення: образність відтворення дійсності у творі та його естетична довершеність як єдність змісту і форми. При цьому якість художньої форми, як слушно наголошує Ю. Юхимик, визначається володінням “школою майстерності”, здатністю добрати особливий комплекс засобів художньої виразності, забезпечити неповторність художнього конструювання, продемонструвати дійсно творче натхнення й оригінальність творчого мислення [11, 23].

По-третє, невідповідність між зображальною грамотою в опануванні їі академічних основ та якістю образотворення в контексті відтворення ілюзії предметів і явищ дійсності. Іншими словами, грамотне зображення не завжди засвідчує непересічний художній смак його автора. На переконання В. Бичкова, “художність $є$ свого роду “відбитком”, матеріалізацією високого смаку майстра в його творі за умови, звісно, що він вільно володіє технічними навичками у своєму виді мистецтва" $[2,225]$. Згідно 3 цим, художність охоплює весь процес становлення твору згідно 3 нормами і вимогами мистецтва - мімезису (наслідування природи), композиції (досягнення цілісності складників твору), художнього образу (єдність змісту і форми й оригінальність ідеї).

Висновки та перспективи подальших розвідок. Фокус результативності базового професійного етапу образотворчої підготовки майбутніх фахівців мистецьких спеціальностей доцільно регламентувати такими професіографічними дескрипторами, як “зображальна грамота” і “художня майстерність”. Оскільки в артпедагогічному процесі має місце дисбаланс у формуванні цих професійно-особистісних якостей студентів, причина виникнення якого полягає в наданні переваги одному 3 критеріїв реалістичності й образності в досягненні художньої якості виконання навчально-творчих завдань із фахових дисциплін, то весь образотворчий вишкіл необхідно спрямувати на гармонійне поєднання компетентнісного, художньо-творчого й акмеологічного підходів, що становить перспективу для подальшого вдосконалення методологічних засад мистецької освіти.

\section{ЛІТЕРАТУРА}

1. Безклубенко С. Мистецтво: терміни та поняття: енциклопед. вид.: у 2-х т. Київ, 2010. Т. 2. $256 \mathrm{c}$

2. Бычков В. В., Маньковская Н. Б. Художественность как метафизическое основание эстетического опыта и критерий определения подлинности искусства. Вестник славянских культур. 2017. № 43. C. 220-241.

3. Гончаренко С. У. Український педагогічний енциклопедичний словник. Вид. 2- ге, доп. Рівне, $2011.552 \mathrm{c}$.

4. Гордаш А. М. Формування основ художньої майстерності майбутніх учителів образотворчого мистецтва у процесі фахової підготовки: автореф. дис. ... канд. пед. наук, спец.: 13.00.04. Умань, $2020.20 \mathrm{c}$.

5. Гриценко В. С. Повертаючись до розмови про художній образ. Гуманітарний часопис. 2012. № 4. C. 24-31.

6. Енциклопедія освіти / Академія пед. наук України; голов. ред. В. Г. Кремень. Київ, 2008. $1040 \mathrm{c}$

7. Іващенко В. Л. Фах і спеціальність: концептуальна диференціація еквіполентів. Науковий вісник Ізмаӥльського державного педагогічного інституту. Серія Історичні науки. Педагогічні науки. Філологічні науки. 2001. № 11. С. 92-95.

8. Левин И. Л. Парадигмальный анализ моделей архитектурно-художественного образования: классификация, перспективы реализации. Казанский педагогический журнал. 2016. № 4 (117). С. 53-58.

9. Пономарьова О. М. Методологічні засади підготовки фахівців мистецьких спеціальностей у вищих навчальних закладах України. Наукові записки Ніжсиського державного університету ім. Миколи Гоголя. Сер.: Психолого-педагогічні науки. 2013. № 1. С. 56-60.

10. Сотська Г. І. Обгрунтування сутності творчості у змісті підготовки сучасного педагога. ScienceRise. Pedagogical Education. 2016. № 11. C. $10-13$.

11. Юхимик Ю. В. "Contemporary Art": симуляція мистецтва. Актуальні проблеми історії, теорії та практики художньоі культури. 2013. № 31. С. 17-24.

12. The framework of qualifications for the European Higher Education Area. Available at: http:/ /www.ehea.info/Uploads/Documents/QF-EHEAMay2005.pdf (Accessed 12 Febr. 2020).

\section{REFERENCES}

1. Bezklubenko, S. (2010). Mystetstvo: terminy ta poniattia [Art: Terms and Concepts]. in 2 volumes. Volume 2. Kyiv. 256 p. [in Ukrainian]. 
2. Bychkov, V. V. \& Mankovskaya, N. B. (2017). Khudozhestvennost kak metafizicheskoe osnovanie esteticheskogo opyta i kriteriy opredeleniya podlinnosti iskusstva [Artistry as a metaphysical basis of aesthetic experience and a criteria for determining the authenticity of art]. Bulletin of Slavic Cultures. No. 43. pp. 220-241. [in Russian].

3. Honcharenko, S. (2011). Ukrainskyi pedahohichnyi slovnyk [Ukrainian Pedagogical Dictionary]. Kyiv, 552 p. [in Ukrainian].

4. Hordash, A. M. (2020). Formuvannia osnov khudozhnoi maisternosti maibutnikh uchyteliv obrazotvorchoho mystetstva u protsesi fakhovoi pidhotovky [The Fundamentals to Artistic Skills Formation of Would-Be Teachers of Fine Arts in the Specific Training Process]. Extended abstract of candidate's thesis. Uman, 20 p. [in Ukrainian].

5. Hrytsenko, V. S. (2012). Povertaiuchys do rozmovy pro khudozhnii obraz [Getting back to the talk about the artistic image]. Humanities magazine. No. 4. pp. 24-31. [in Ukrainian].

6. Kremen, V. H. (Ed.). (2008). Entsyklopediia osvity [Encyclopedia of Education]. Kyiv, 1040 p. [in Ukrainian].

7. Ivashchenko, V. L. (2001). Fakh i spetsialnost: kontseptualna dyferentsiatsiia ekvipolentiv [Profession and specialty: conceptual differentiation of ekvipolent]. Scientific Bulletin of the Izmayil State Pedagogical Institute. Historical Sciences Series. Pedagogical sciences. Philological sciences. No. 11. pp. 92-95. [in Ukrainian].
8. Levin, I. L. (2016). Paradigmalnyy analiz modeley arkhitekturno-khudozhestvennogo obrazovaniya: klassifikatsiya, perspektivy realizatsii [Paradigmatic analysis of architectural and artistic education models: classification, implementation prospects]. Kazan pedagogical journal. No. 4 (117). pp. 53-58. [in Russian].

9. Ponomarova, O. M. (2013). Metodolohichni zasady pidhotovky fakhivtsiv mystetskykh spetsialnostei u vyshchykh navchalnykh zakladakh Ukrainy [Methodological bases of the training of professionals of art specialties at higher educational establishments of Ukraine]. Scientific notes of Nizhyn Mykola Hohol State University. Ser .: Psychological and pedagogical sciences. No. 1. pp. 56-60. [in Ukrainian].

10. Sotska, H. I. (2016). Obhruntuvannia sutnosti tvorchosti u zmisti pidhotovky suchasnoho pedahoha [Summaryzing of the essence of creativity in the content of the modern teacher's training]. ScienceRise. Pedagogical Education. No.11. pp. 10-13. [in Ukrainian].

11. Iukhymyk, Yu. V. (2013). "Contemporary Art": symuliatsiia mystetstva ["Contemporary Art": art simulation]. Current issues of history, theory and practice of art culture. No. 31. pp. 17-24. [in Ukrainian].

12. The framework of qualifications for the European Higher Education Area. Available at: http:/ /www.ehea.info/Uploads/Documents/QF-EHEAMay2005.pdf(Accessed 12 Febr. 2020). [in English].

Стаття надійшла до редакції 05.04.2020

\section{G58080

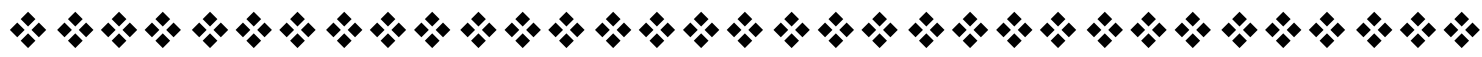 \\ "Слова, що дають знання - найцінніші".}

Apuстотель

давньогрецький білософ, вчений

“Освіта повинна бути істинною, повною, ясною іміщною”.

Унсур Аль-Маaлі (Кей Кабус) персидський письменник

"Якщо запастися терпінням $і$ виявити старання, то посіяні насіння знання неодмінно дадуть добрі сходи. Навчання корінь гіркий, такплід солодкий”.

\section{G58080}

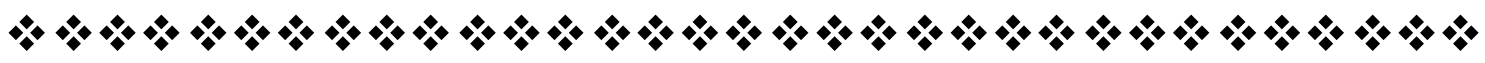

